\title{
Organizational Justice In Higher Education: Perceptions Of Taiwanese Professors And Staffs
}

Jason Cheng-Cheng Yang, National Chiayi University, Taiwan

I-Pei Cho, Chia Nan University of Pharmacy \& Science, Taiwan

\begin{abstract}
Higher education in Asia is becoming more prominent according to Western higher education researchers, but it is also being influenced by globalization, resulting in two types of structural inequality in higher education. Organizational justice relates to positive developments of educational organizations. It refers to the sense of fairness and equality on aspects of organization policies and regulations relating to individual interests perceived by organizations' internal members. This research first reviews the related literature to identify internal factors in the concept of organizational justice in higher education. The author designed a survey questionnaire to assess professors' perceptions of organizational justice at their universities. The author sent out the questionnaires to Taiwanese professors with different research expertise at different universities. This research divided organizational justice into distributive justice, procedure justice, interpersonal justice, and information justice. Ultimately, 180 valid questionnaires were collected and analyzed. Four background variables (gender, age, position, and institutional type) showed statistical correlations with organizational justice in Taiwan's higher education institutions.
\end{abstract}

Keywords: Organizational Justice in Higher Education; Structural Inequality at University, Taiwan

\section{INTRODUCTION}

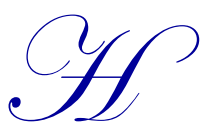

igher education in Asia is becoming more prominent according to higher education researchers (Levin, 2010; Marginson, Kaur, \& Sawir, 2011). As Mok (2015) pointed out that the impact of international rankings on higher education in Asia had pushed Asian governments to apply various strategies (i.e., funding and quality assurance) to respond to the global competition of universities. Higher education in Asia is also being influenced by globalization, resulting in two types of structural inequality in higher education (Naidoo, 2010. One type is outside the national context in the globalized society, where differences of institutions and nations will be larger due to different types of power that global linking institutions and nations possess. Another type is in the national context, where the stratification among higher education institutions in a nation will also be larger, leading to universities favored by national governments possessing many more resources than those not chosen (Marginson, Kaur, \& Sawir, 2011). Thus, studying inequality issues in higher education is important in the context of globalization. Specifically, three areas should be studied: the inequality of higher education competitions between internationalized research universities; the issue of academic resource inequality of higher education institutions; and the sense of equality in higher education institutions.

One significant case of the current inequality issues in the context of Taiwan higher education is the over-emphasis of academic research productions. The global university rankings gave high weights to numbers and citations of journal articles. The number of journal articles influenced academic resource distribution in the universities. As the result, the sense of inequality arises amongst professors in Taiwan. Chou (2014) pointed out this problem in her article "The SSCI Syndrome in Taiwan's Academia". She argued that the over-emphasis on quantitative indicators of higher education evaluations used by the Taiwanese government and universities has caused reactions amongst academic members across disciplines. 
Organizational justice relates to positive developments of educational organizations (Colquitt, Conlon, Wesson, Porter, \& Ng, 2001). It refers to the sense of fairness and equality on aspects of organization policies and regulations relating to individual interests perceived by organizations' internal members (Folger \& Cropanzano, 1998). There are two types of organizational justice. The first type focuses on the fairness and justice of organizational policies and regulations. The second type involves internal members' perceptions of the fairness and justice of these policies and regulations (Aryee, Budhwar, \& Chen, 2002). Organizational members perceive organizational justice as positively relating to their job satisfaction, trust, commitment, and performance (Aryee, Budhwar, \& Chen, 2002).

This research first reviews the related literature to identify internal factors in the concept of organizational justice in higher education. The author designed a survey questionnaire to assess professors' perceptions of organizational justice at their universities. The author sent out the questionnaires to Taiwanese professors with different research expertise at different universities.

\section{LITERATURE REVIEW}

Organizational justice considers issues related to organizational members' attitudes on the fairness of organizational regulations and policies (Folger \& Cropanzano, 1998). Such justice is about rules and social norms that can define the distribution of resources within an organization. These resources include rewards or punishments as well as treatment among members and interpersonal relationships (Bies \& Tripp, 1995).

Organizational justice includes three factors: distributive justice, procedure justice, and interpersonal justice. To address the importance of information sharing and information access in society, Colquitt (2001) added one more factor, information justice, to the broad concept of organizational justice.

The theoretical basis of organizational justice is social exchange theory, which explains rational actions and decisions related to rewards for human beings. Decisions about human behavior come from objective cost-efficiency analyses and action choices (Homans, 1961). As the theoretical foundation of organizational justice, social exchange theory formulates the thinking that organizational members' perceptions will influence their actual actions. Another important theory relating to organizational justice is equity theory, developed by Adams (1965), which further explains how organizational members compare their inputs in the organization and their returns/outcomes as well as how these comparisons in their minds influence their actions.

Social exchange theory and equity theory are the theoretical basis of distributive justice. Thibaut and Walker (1975) highlighted the importance of the process of distributing resources within an organization; thus, procedure justice became another important factor. In the 1980s, Bies and Moag (1986) argued that procedure justice is relating to interpersonal relationships among organizational members. When organizational leaders distribute their resources, their interpersonal relationships with workers influence the distribution results, which is why interpersonal justice became the third factor of organizational justice. Finally, the global and highly developed information communication Technology (ICT) strengthened the importance of information access and information exposure's influence on distribution and procedure; thus, information justice is the fourth factor in organizational justice (Greenberg, 1993).

Regarding empirical studies of organizational justice in higher education, Martinson, Anderson, Crain, and Vries (2006) sent questionnaires to scientific researchers and scholars to explore their perceptions of organizational justice inside research institutes and how their perceptions influenced their scientific research behaviors. Colquitt (2001) sent questionnaires to 301 third-grade university students; the research results supported the four factors of organizational justice at the higher education level. The four factors-distribution justice, procedure justice, interpersonal justice, and information justice - showed positive correlations with organizational satisfaction as well as participants' collective self-esteem and ratings of leaders.

\section{RESEARCH METHOD}

Based on the literature review, this research constructed a questionnaire on organizational justice at higher education institutions. Figure 1 depicts the conceptual framework of organizational justice at higher education institutions. As 
the literature review suggested, this research divided organizational justice of higher education into four factors: distributive justice, procedure justice, interpersonal justice, and information justice. This research conceptualized indicators that can represent distributive justice as the equal distributions of accountability, salary, and reward of all members at higher education institutions. The conceptual indicators of procedure justice are consistent, are ethical, and apply respect in the administrative procedures at higher education institutions. Regarding interpersonal justice, indicators include the sense of equality among positions, gender, ethnicity, social, economic backgrounds. Indicators of information justice are the degree of understandability, the variety of medias, and instantaneousness.

Figure 1. Conceptual framework of organizational justice at higher education institutions

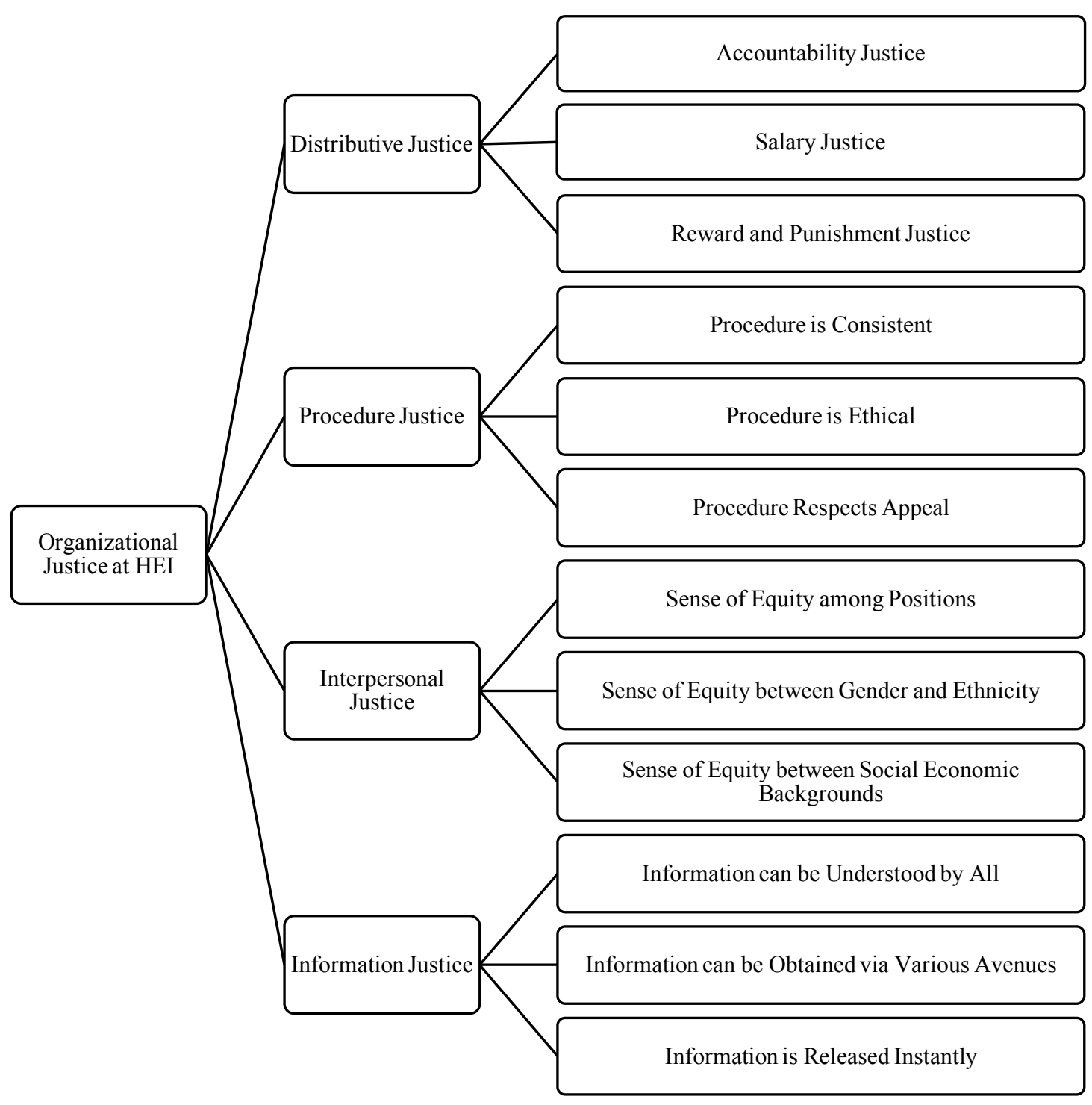

Table 1 summarizes the Cronbach alpha values and factor loadings of all items. The Cronbach alpha value of all items is .963 , while all items' Cronbach alpha values when the items deleted were less than or equal to .963 . 
Table 1. Cronbach Alpha Values of All Items of Organizational Justice in Higher Education

\begin{tabular}{|c|c|}
\hline Items of Organizational Justice in Higher Education & $\begin{array}{l}\text { Cronbach } \\
\text { Alpha When } \\
\text { Item Deleted }\end{array}$ \\
\hline Administrative works are distributed equally to all staffs at my university & .961 \\
\hline Hours of work are equal among all staffs at my university & .962 \\
\hline Resources and equipment are distributed equally to different offices at my university & .961 \\
\hline The equal distribution of work rewards to all staffs at my university & .961 \\
\hline Regulations of rewards and fines are equal to all staffs at my university & .961 \\
\hline Rights of all staffs are equal at my university & .962 \\
\hline Accountability of all staffs are equal at my university & .961 \\
\hline Academic and administrative committees are established based on equal procedures at my university & .963 \\
\hline Administrative decisions are made based on equal procedures at my university & .961 \\
\hline Decision procedures of meeting are transparent and open at my university & .961 \\
\hline Administrative decisions are made based on accurate and the latest information at my university & .961 \\
\hline Administrative decisions can equally consider university development and rights of staffs at my university & .961 \\
\hline My university periodically examines and fixes inequality problems of administrative procedures & .961 \\
\hline Staffs in different positions are treated equally at my university & .962 \\
\hline Staffs of different ethnicities are treated equally at my university & .963 \\
\hline Male and female staffs are treated equally at my university & .962 \\
\hline Staffs with different appearances are treated equally at my university & .963 \\
\hline Staffs with different economic income backgrounds are treated equally at my university & .962 \\
\hline Staffs who have relatives or friends in a high position in the government are not treated better at my university & .961 \\
\hline Communication among staffs flows freely at my university & .960 \\
\hline Information is instantly released to all staffs at my university & .961 \\
\hline Information can be easily obtained from different offices at my university & .962 \\
\hline The information divide between positions is low at my university & .962 \\
\hline Information can be obtained from different medias (paper, the internet, audio, and video) at my university & .961 \\
\hline
\end{tabular}

\section{FINDINGS AND DISCUSSION}

The means and standard deviations of four factors and the whole concept of organizational justice in higher education are in table 2. The data in this table indicate that participants perceived a higher sense of justice at their university on the factor of interpersonal justice. Distributive justice is the factor that participants perceived to provide the least sense of justice in the context of their higher education environment.

Table 2. Means and SDs of Organizational Justice in Higher Education for All Items and Four Factors

\begin{tabular}{l|c|c|c}
\hline \multicolumn{1}{c|}{ Factors } & N & Mean & SD \\
\hline Organizational Justice in Higher Education (all items) & 180 & 3.4752 & .71524 \\
\hline Distributive Justice & 180 & 3.0143 & .85782 \\
\hline Procedure Justice & 180 & 3.5880 & .77664 \\
\hline Interpersonal Justice & 180 & 3.8472 & .75587 \\
\hline Information Justice & 180 & 3.5389 & .77679 \\
\hline
\end{tabular}

The means and standard deviations of all items of organizational justice in higher education are in table 3 . The participants perceived a higher sense of equality about ethnicity, economic background, gender, and appearance. However, one notable finding is that participants perceived a lower sense of equality when their colleagues have relatives or friends in a high position in the government. Social connections or social capital could be an influential element or determinant for organizational justice in higher education. The participants also perceived a lower sense of equality for hours of work between colleagues and rewards at work. Thus, the potential problem of the consistency between workload and reward balance is an important consideration when managing higher education institutions in Taiwan. 
Table 3. Means and SDs of Organizational Justice in Higher Education for Each Item

\begin{tabular}{|c|c|c|c|c|}
\hline Items of Organizational Justice in Higher Education & $\mathbf{N}$ & Mean & SD & Order \\
\hline Administrative works are distributed equally to all staffs at my university & 180 & 3.122 & 1.0338 & 19 \\
\hline Hours of work are equal among all staffs at my university & 180 & 2.772 & 1.0239 & 24 \\
\hline Resources and equipment are distributed equally to different offices at my university & 180 & 3.222 & .9369 & 17 \\
\hline The equal distribution of work rewards to all staffs at my university & 180 & 2.844 & 1.0074 & 23 \\
\hline Regulations of rewards and fines are equal to all staffs at my university & 180 & 3.072 & 1.0085 & 20 \\
\hline Rights of all staffs are equal at my university & 180 & 3.061 & .9869 & 21 \\
\hline Accountability of all staffs are equal at my university & 180 & 3.006 & 1.0056 & 22 \\
\hline $\begin{array}{l}\text { Academic and administrative committees are established based on equal procedures } \\
\text { at my university }\end{array}$ & 180 & 3.978 & .8253 & 5 \\
\hline Administrative decisions are made based on equal procedures at my university & 180 & 3.856 & .8530 & 6 \\
\hline Decision procedures of meeting are transparent and open at my university & 180 & 3.583 & .9909 & 9 \\
\hline $\begin{array}{l}\text { Administrative decisions are made based on accurate and the latest information at my } \\
\text { university }\end{array}$ & 180 & 3.433 & .8787 & 13 \\
\hline $\begin{array}{l}\text { Administrative decisions can equally consider university development and rights of } \\
\text { staffs at my university }\end{array}$ & 180 & 3.161 & .9981 & 18 \\
\hline $\begin{array}{l}\text { My university periodically examines and fixes inequality problems of administrative } \\
\text { procedures }\end{array}$ & 180 & 3.517 & .9600 & 12 \\
\hline Staffs in different positions are treated equally at my university & 180 & 3.528 & .9884 & 11 \\
\hline Staffs of different ethnicities are treated equally at my university & 180 & 4.156 & .7536 & 1 \\
\hline Male and female staffs are treated equally at my university & 180 & 4.033 & .8516 & 3 \\
\hline Staffs with different appearances are treated equally at my university & 180 & 4.006 & .8555 & 4 \\
\hline $\begin{array}{l}\text { Staffs with different economic income backgrounds are treated equally at my } \\
\text { university }\end{array}$ & 180 & 4.044 & .8576 & 2 \\
\hline $\begin{array}{l}\text { Staffs who have relatives or friends in a high position in the government are not } \\
\text { treated better at my university }\end{array}$ & 180 & 3.317 & 1.1698 & 16 \\
\hline Communication among staffs flows freely at my university & 180 & 3.406 & .9955 & 15 \\
\hline Information is instantly released to all staffs at my university & 180 & 3.606 & .8875 & 8 \\
\hline Information can be easily obtained from different offices at my university & 180 & 3.556 & .8602 & 10 \\
\hline The information divide between positions is low at my university & 180 & 3.433 & 1.0362 & 13 \\
\hline $\begin{array}{l}\text { Information can be obtained from different medias (paper, the internet, audio, and } \\
\text { video) at my university }\end{array}$ & 180 & 3.694 & .8528 & 7 \\
\hline
\end{tabular}

Table 4 summarizes the result of $t$-tests on gender differences in the perception of organizational justice in higher education. From the macro perspective, female colleagues perceived a lower sense of justice among all factors than their male colleagues. The $t$-test results show a significant difference in the factors of distributive justice, procedure justice, interpersonal justice, and information justice. Gender is an important variable of organizational justice in the context of Taiwan's higher education.

Table 4. T- of Gender and Factors of Organizational Justice in Higher Education

\begin{tabular}{|c|c|c|c|c|c|c|}
\hline Factors & Gender & $\mathbf{N}$ & Mean & SD & $t$ Value & Sig. \\
\hline \multirow{2}{*}{ HEOJ ALL } & Male & 89 & 3.6259 & .76021 & \multirow{2}{*}{2.851} & \multirow{2}{*}{$.005^{* *}$} \\
\hline & Female & 91 & 3.3278 & .63871 & & \\
\hline \multirow{2}{*}{ Distributive Justice } & Male & 89 & 3.1910 & .90015 & \multirow{2}{*}{2.785} & \multirow{2}{*}{$.006^{* *}$} \\
\hline & Female & 91 & 2.8414 & .78114 & & \\
\hline \multirow{2}{*}{ Procedure Justice } & Male & 89 & 3.7303 & .87093 & \multirow{2}{*}{2.459} & \multirow{2}{*}{$.015^{*}$} \\
\hline & Female & 91 & 3.4487 & .64678 & & \\
\hline \multirow{2}{*}{ Interpersonal Justice } & Male & 89 & 3.9682 & .80241 & \multirow{2}{*}{2.144} & \multirow{2}{*}{$.033^{*}$} \\
\hline & Female & 91 & 3.7289 & .69150 & & \\
\hline \multirow{2}{*}{ Information Justice } & Male & 89 & 3.6989 & .75746 & \multirow{2}{*}{2.784} & \multirow{2}{*}{$.006^{* *}$} \\
\hline & Female & 91 & 3.3824 & .76748 & & \\
\hline
\end{tabular}

${ }^{*} p<.05 ; * * p<.01 ; * * * p<.001$ 
Table 5 summarizes the $t$-test results related to the perception of organizational justice in higher education based on institution type differences. From the macro perspective, colleagues at national universities tended to perceive a lower sense of justice among all factors than their colleagues at private institutions. The $t$-test results show statistically significant differences in distributive justice, interpersonal justice, and information justice.

Table 5. T-test of Institutional Type (National and Private) and Factors of Organizational Justice in Higher Education

\begin{tabular}{|c|c|c|c|c|c|c|}
\hline Factors & Types & $\mathbf{N}$ & Mean & SD & $t$ Value & Sig. \\
\hline \multirow{2}{*}{ HEOJ ALL } & National & 62 & 3.2769 & .78312 & \multirow{2}{*}{-2.746} & \multirow{2}{*}{$.007^{* *}$} \\
\hline & Private & 118 & 3.5794 & .65660 & & \\
\hline \multirow{2}{*}{ Distributive Justice } & National & 62 & 2.8134 & .86010 & \multirow{2}{*}{-2.305} & \multirow{2}{*}{$.022^{*}$} \\
\hline & Private & 118 & 3.1199 & .84111 & & \\
\hline \multirow{2}{*}{ Procedure Justice } & National & 62 & 3.4328 & .83930 & \multirow{2}{*}{-1.958} & \multirow{2}{*}{.052} \\
\hline & Private & 118 & 3.6695 & .73217 & & \\
\hline \multirow{2}{*}{ Interpersonal Justice } & National & 62 & 3.6747 & .90406 & \multirow{2}{*}{-2.032} & \multirow{2}{*}{$.045^{*}$} \\
\hline & Private & 118 & 3.9379 & .65110 & & \\
\hline \multirow{2}{*}{ Information Justice } & National & 62 & 3.2613 & .87635 & \multirow{2}{*}{-3.318} & \multirow{2}{*}{$.001^{* *}$} \\
\hline & Private & 118 & 3.6847 & .67856 & & \\
\hline
\end{tabular}

$* p<.05 ; * * p<.01 ; * * * p<.001$

Table 6 summarizes the $t$-test results related to the perception of organizational justice in higher education based on institutional history differences. From the macro perspective, colleagues at older universities tended to perceive a lower sense of justice among all factors (despite the interpersonal justice factor) than colleagues at newer institutions. The $t$-test results show no statistically significant differences in the factors.

Table 6. T-test of University History and Factors of Organizational Justice in Higher Education

\begin{tabular}{|c|c|c|c|c|c|c|}
\hline Factors & History & $\mathbf{N}$ & Mean & SD & $t$ Value & Sig. \\
\hline \multirow{2}{*}{ HEOJ ALL } & $11-20 \mathrm{Y}$ & 26 & 3.5641 & .67456 & \multirow{2}{*}{.684} & \multirow{2}{*}{.495} \\
\hline & $>21 \mathrm{Y}$ & 154 & 3.4602 & .72290 & & \\
\hline \multirow{2}{*}{ Distributive Justice } & $11-20 \mathrm{Y}$ & 26 & 3.2637 & .72696 & \multirow{2}{*}{1.610} & \multirow{2}{*}{.109} \\
\hline & $>21 \mathrm{Y}$ & 154 & 2.9722 & .87304 & & \\
\hline \multirow{2}{*}{ Procedure Justice } & $11-20 \mathrm{Y}$ & 26 & 3.6923 & .72678 & \multirow{2}{*}{.740} & \multirow{2}{*}{.460} \\
\hline & $>21 \mathrm{Y}$ & 154 & 3.5703 & .78562 & & \\
\hline \multirow{2}{*}{ Interpersonal Justice } & $11-20 \mathrm{Y}$ & 26 & 3.6987 & .76161 & \multirow{2}{*}{-1.084} & \multirow{2}{*}{.280} \\
\hline & $>21 \mathrm{Y}$ & 154 & 3.8723 & .75451 & & \\
\hline \multirow{2}{*}{ Information Justice } & $11-20 \mathrm{Y}$ & 26 & 3.6692 & .81769 & \multirow{2}{*}{.925} & \multirow{2}{*}{.356} \\
\hline & $>21 \mathrm{Y}$ & 154 & 3.5169 & .77026 & & \\
\hline
\end{tabular}

${ }^{*} p<.05 ; * * p<.01 ; * * * p<.001$

Table 7 summarizes the ANOVA results of the four factors of organizational justice in higher education among participants' positions. From the macro perspective, adjunct staffs tended to perceive a lower sense of justice than regular staffs and faculty. The ANOVA analysis found statistically significant differences between faculty and staffs. Faculty members usually have higher administrative positions than staffs in the Taiwanese higher education system. Taiwan's law provides universities with autonomy, and professors play a key role in the shared governance system of higher education in Taiwan. The position is an important variable to consider in studies of organizational justice in higher education, as confirmed by this study. 
Table 7. ANOVA of Position and Factors of Organizational Justice in Higher Education

\begin{tabular}{|c|c|c|c|c|c|c|}
\hline Factors & Position & $\mathbf{N}$ & Mean & SD & F Value & Post-Hoc \\
\hline \multirow{3}{*}{ HEOJ ALL } & (1)Faculty & 38 & 3.9879 & .69167 & \multirow{3}{*}{$16.490^{* * *}$} & \multirow{3}{*}{$\begin{array}{l}(1)>(2) \\
(1)>(3)\end{array}$} \\
\hline & (2)Regular Staff & 86 & 3.4268 & .67631 & & \\
\hline & (3)Adjunct Staff & 56 & 3.2016 & .61215 & & \\
\hline \multirow{3}{*}{ Distributive Justice } & (1)Faculty & 38 & 3.5827 & .91043 & \multirow{3}{*}{$12.359^{* * *}$} & \multirow{3}{*}{$\begin{array}{l}(1)>(2) \\
(1)>(3)\end{array}$} \\
\hline & (2)Regular Staff & 86 & 2.9136 & .83307 & & \\
\hline & (3)Adjunct Staff & 56 & 2.7832 & .68647 & & \\
\hline \multirow{3}{*}{ Procedure Justice } & (1)Faculty & 38 & 4.1842 & .61609 & \multirow{3}{*}{$17.483^{* * *}$} & \multirow{3}{*}{$\begin{array}{l}(1)>(2) \\
(1)>(3)\end{array}$} \\
\hline & (2)Regular Staff & 86 & 3.4845 & .78658 & & \\
\hline & (3)Adjunct Staff & 56 & 3.3423 & .65399 & & \\
\hline \multirow{3}{*}{ Interpersonal Justice } & (1)Faculty & 38 & 4.2632 & .73177 & \multirow{3}{*}{$11.808^{* * *}$} & $(1)>(2)$ \\
\hline & (2)Regular Staff & 86 & 3.8663 & .67680 & & $(1)>(3)$ \\
\hline & (3)Adjunct Staff & 56 & 3.5357 & .75660 & & $(2)>(3)$ \\
\hline \multirow{3}{*}{ Information Justice } & (1)Faculty & 38 & 3.9895 & .70970 & \multirow{3}{*}{$12.636^{* * *}$} & $(1)>(2)$ \\
\hline & (2)Regular Staff & 86 & 3.5488 & .73641 & & $(1)>(3)$ \\
\hline & (3)Adjunct Staff & 56 & 3.2179 & .73586 & & $(2)>(3)$ \\
\hline
\end{tabular}

Table 8 summarizes the ANOVA results of the four factors of organizational justice in higher education among participants' ages. From the macro perspective, younger colleagues tended to perceive a lower sense of justice than their older colleagues. The ANOVA analysis found statistically significant differences between the $26-35$ age group and the $46-55$ age group. Colleagues between 46 and 55 years old tended to have a higher sense of justice than the youngest age group.

Table 8. ANOVA of Age and Factors of Organizational Justice in Higher Education

\begin{tabular}{|c|c|c|c|c|c|c|}
\hline Factors & Age & $\mathbf{N}$ & Mean & SD & F Value & Post-Hoc \\
\hline \multirow{4}{*}{ HEOJ ALL } & (1)26-35 & 68 & 3.2604 & .48202 & \multirow{4}{*}{$4.873^{* *}$} & \multirow{4}{*}{$(3)>(1)$} \\
\hline & (2) $36-45$ & 49 & 3.4549 & .87565 & & \\
\hline & (3) $46-55$ & 52 & 3.7220 & .76775 & & \\
\hline & $(4)>56$ & 11 & 3.7273 & .45998 & & \\
\hline \multirow{4}{*}{ Distributive Justice } & (1)26-35 & 68 & 2.7983 & .60772 & \multirow{4}{*}{$2.916^{*}$} & \multirow{4}{*}{$(3)>(1)$} \\
\hline & (2) $36-45$ & 49 & 3.0321 & 1.04624 & & \\
\hline & (3)46-55 & 52 & 3.2418 & .93466 & & \\
\hline & $(4)>56$ & 11 & 3.1948 & .60364 & & \\
\hline \multirow{4}{*}{ Procedure Justice } & (1)26-35 & 68 & 3.3725 & .59581 & \multirow{4}{*}{$3.796^{*}$} & \multirow{4}{*}{$(3)>(1)$} \\
\hline & (2) $36-45$ & 49 & 3.5884 & .86810 & & \\
\hline & (3)46-55 & 52 & 3.8141 & .87176 & & \\
\hline & $(4)>56$ & 11 & 3.8485 & .51884 & & \\
\hline \multirow{4}{*}{ Interpersonal Justice } & (1)26-35 & 68 & 3.6324 & .60646 & \multirow{4}{*}{$4.749^{* *}$} & \multirow{4}{*}{$(3)>(1)$} \\
\hline & (2) $36-45$ & 49 & 3.8129 & .86243 & & \\
\hline & (3) $46-55$ & 52 & 4.0769 & .80064 & & \\
\hline & $(4)>56$ & 11 & 4.2424 & .39696 & & \\
\hline \multirow{4}{*}{ Information Justice } & (1) $26-35$ & 68 & 3.3265 & .57708 & \multirow{4}{*}{$5.333^{* *}$} & \multirow{4}{*}{$(3)>(1)$} \\
\hline & (2) $36-45$ & 49 & 3.4571 & .95219 & & \\
\hline & (3) $46-55$ & 52 & 3.8577 & .74448 & & \\
\hline & $(4)>56$ & 11 & 3.7091 & .70065 & & \\
\hline
\end{tabular}

\section{CONCLUSION}

Globalization has intensified competition among higher education institutions in the world. Asia is a key region experiencing this trend. Thus, research universities in Asia are now pursuing higher rankings and recruiting talented students and scholars (Deem, Mok, \& Lucas, 2008). Research articles predict that professors' workloads will increase more than ever. Competition among professors in higher education will also increase. The term "academic 
capitalism" can reflect this kind of phenomenon, but the perception of organizational justice in higher education-an important psychological construct that can predict organizational health and well-being - is neglected in this global context and studies of higher education.

This research constructed a questionnaire to assess the sense and perceptions of organizational justice in higher education institutions for staff and faculty members in Taiwan based on a review of the literature and expert opinions. This research divided organizational justice into distributive justice, procedure justice, interpersonal justice, and information justice. The 24 items on the questionnaire represent these four factors. This research administered questionnaires to 250 staffs and professors at national and private universities in the southern region of Taiwan. Ultimately, 180 valid questionnaires were collected and analyzed. Four background variables—gender, age, position, and institutional type-showed statistical correlations with organizational justice in Taiwan's higher education institutions. Staffs and professors at Taiwanese universities tended to perceive a higher sense of justice for interpersonal justice but the lowest sense of justice for distributive justice. Staffs and professors at Taiwanese universities tended to perceive a higher sense of equality related to ethnicity, economic background, gender, and appearance but a lower sense of justice when their colleagues had social connections or social capital. Professors and staffs also perceived a lower sense of justice related to hours of work and rewards from work.

\section{AUTHOR BIOGRAPHIES}

Jason Cheng-Cheng Yang is currently an Associate Professor at National Chiayi University, Taiwan. He interested in studies of higher education administration, higher education policy, and education development in Asia.

I-Pei Cho is currently an administrator at Chia Nan University of Pharmacy \& Science, Taiwan. Her research interests include educational administration and higher education.

\section{REFERENCES}

Adams, J. S. (1965). Inequity in social exchange. Advances in Experimental Social Psychology, 2, 267-299.

Altbach, P. G. (2007). Empires of knowledge and development. In P. G. Altbach \& J. Balan (Eds.), World class worldwide: Transforming research universities in Asia and Latin America, 1-28. Baltimore, MD: The Johns Hopkins University Press.

Aryee, S., Budhwar, P. S. \& Chen, Z. X. (2002). Trust as a mediator of the relationship between organizational justice and work outcomes: Test of a social exchange model. Journal of Organizational Behavior, 23, 267-285.

Bies, R. J., \& Moga, J. F. (1986). Interactional justice: Communication criteria of fairness. In R. J. Lewicki, B. H. Sheppard, \& M. H. Bazerman (Eds.), Research on negotiations in organizations, 1, 43-55. Greenwich, CT: JAI Press.

Bies, R. J. \& Tripp, T. M. (1995). The use and abuse of power: Justice as social control. In R. Cropanzano \& K. M. Kacmar (Eds.), Organizational politics, justice, and support: Managing the social climate of work organizations, 131-145. New York: Quorum Books.

Chou, C. P. (2014). The SSCI syndrome in Taiwan's academia. Education Policy Analysis Archives, 22(29), 1-18.

Colquitt, J. A. (2001). On the dimensionality of organizational justice: A construct validation of a measure. Journal of Applied Psychology, 86(3), 386-400.

Colquitt, J. A., Conlon, D. E., Wesson, M. J., Porter, C. O. L. H., \& Ng, K. Y. (2001). Justice at the millennium: A meta-analytic review of 25 years of organizational justice research. Journal of Applied Psychology, 86(3), 425-445.

Deem, R., Mok, K. \& Lucas, L. (2008). Transforming higher education in whose image? Exploring the concept of the 'worldclass' university in Europe and Asia. Higher Education Policy, 21, 83-97.

Findlay, A. M., King, R., Smith, F. M., Geddes, A. \& Skeldon, R. (2011). World class? An investigation of globalisation, difference and international student mobility. Transactions of the Institute of British Geographers, 37(1), 118-131.

Folger, R. \& Cropanzano, R. (1998). Organizational justice and human resource management. Thousand Oaks, Sage Publications.

Greenberg, J. (1993). The social side of fairness: Interpersonal and informational classes of organizational justice. In R. Cropanzano (Ed.), Justice in the workplace: Approaching fairness in human resource management, 79-103. Hillsdale, NJ: Erlbaum.

Homans, G. C. (1961). Social behavior: Its elementary forms. London: Routledge and Kegan Paul.

Levin, R. C. (2010, February 1). The rise of Asia's universities. Speech to the Royal Society, London. Retrieved from http://opa.yale.edu /president/message.aspx?id=91

Marginson, S., Kaur, S., \& Sawir, E. (2011). Global, local, national in the Asia-Pacific. In S. Marginson, S. Kaur, \& E. Sawir (eds.). Higher education in the Asia-Pacific: Strategic responses to globalization. Springer Netherlands. 
Martinson, B. C., Anderson, M. S., Crain, A. L. \& Vries, R. D. (2006). Scientists' perceptions of organizational justice and selfreported misbehaviors. Journal of Empirical Research on Human Research Ethics: An International Journal, 1(1), 5166.

Mok, K. H. (2015). Higher education transformations for global competitiveness: Policy responses, social consequences and impact on the academic profession in Asia. Higher Education Policy, 28(1), 1-15.

Naidoo, R. (2010). Global learning in a neo-liberal age: Implications for development. In E. Unterhalter \& V. Carpentier (eds.). Global inequalities and higher education: Whose interests are you serving?, 66-90. UK, Palgrave Macmillan.

Thibaut, J., \& Walker, L. (1975). Procedural justice: A psychological analysis. Hillsdale, NJ: Erlbaum. 
NOTES 